\title{
PENGARUH MODEL PEMBELAJARAN KOOPERATIF TIPE COOPERATIVE INTEGRATED READING AND COMPOSITI (CIRC) DAN MINAT BACA TERHADAP KETERAMPILAN MENULIS KARANGAN DESKRIPSI SISWA KELAS X SMA NEGERI 1 BANGKINANG
}

\author{
Fenny Anita \\ Universitas Abdurrab, Pekanbaru, Indonesia \\ fenny.anita@univrab.ac.id
}

\begin{abstract}
This research was conducted to explain the effect of the learning model CIRC and reading interest on the results of the descriptive essay writing skills of class X SMA Negeri 1 Bangkinang. This type of research is a quantitative study using a quasi-experimental method and a $2 \times 2$ factorial experimental design. The population of this study was students of class X SMA Negeri 1 Bangkinang. Sampling was done by purposive sampling with a sample size of 60 students. Data collection was carried out using two instruments, namely questionnaires and performance tests. Based on the research results, it can be concluded that four things are as follows. First, the skills of writing essays of descriptions of students taught using the learning model CIRC are better than those taught by conventional learning models of class $X$ students of SMA Negeri 1 Bangkinang. Second, the writing skills of students who have high reading interest who are taught using the learning model $C I R C$ are higher than students who have high reading interest who are taught using the conventional learning model of class $\mathrm{X}$ students of SMA Negeri 1 Bangkinang. Third, the writing skills of students who have low reading interest who are taught using the learning model $C I R C$ are higher than students who have low reading interest who are taught using the conventional learning model of class X students of SMA Negeri 1 Bangkinang. Fourth, there is no interaction between reading interest and learning models in influencing the writing skills of descriptive essays of class X SMA Negeri 1 Bangkinang.
\end{abstract}

Keyword: Essay Description; CIRC; Reading Interest

\begin{abstract}
ABSTRAK
Penelitian ini dilakukan untuk menjelaskan pengaruh model pembelajaran $C I R C$ dan minat baca terhadap hasil keterampilan menulis karangan deskripsi siswa kelas X SMA Negeri 1 Bangkinang. Jenis penelitian ini adala penelitian kuantitatif dengan menggunakan metode eksperimen semu (quasy exsperiment) dan desain eksperimen factorial $2 \times 2$. Populasi penelitian ini adalah siswa kelas $\mathrm{X}$ SMA Negeri 1 Bangkinang. Pengambilan sampel dilakukan dengan cara purposive sampling dengan jumlah sampel 60 orang siswa. Pengumpulan data dilakukan dengan menggunakan dua instrumen, yaitu angket dan tes unjuk kerja. Berdasarkan hasil penelitian dapat disimpulkan empat hal sebagai berikut. Pertama, keterampilan menulis karangan deskripsi siswa yang diajar dengan menggunakan model pembelajaran CIRC lebih baik daripada siswa yang diajar dengan model pembelajaran konvensional siswa kelas X SMA Negeri 1 Bangkinang. Kedua, keterampilan menulis karangan deskripsi siswa yang memiliki minat baca tinggi yang diajar dengan menggunakan model pembelajaran CIRC lebih tinggi dari siswa yang memiliki minat baca tinggi yang diajar menggunakan model pembelajaran konvensional siswa kelas X SMA Negeri 1 Bangkinang. Ketiga, keterampilan menulis karangan deskripsi siswa yang memiliki minat baca rendah yang diajar dengan menggunakan model pembelajaran CIRC lebih tinggi dari siswa yang memiliki minat baca rendah yang diajar menggunakan model pembelajaran konvensional siswa

Pengaruh Model Pembelajaran Kooperatif Tipe Cooperative Integrated Reading And Compositi (CIRC) dan Minat Baca Terhadap Keterampilan Menulis Karangan Deskripsi Siswa Kelas X SMA Negeri 1 Bangkinang
\end{abstract}


kelas X SMA Negeri 1 Bangkinang. Keempat, tidak terdapat interaksi antara minat baca dengan model pembelajaran dalam memengaruhi keterampilan menulis karangan deskripsi siswa kelas $\mathrm{X}$ SMA Negeri 1 Bangkinang.

\section{Kata Kunci: karangan deskrispsi; minat baca; model pembelajaran CIRC}

\section{PENDAHULUAN}

Bahasa merupakan sarana untuk berkomunikasi dengan orang lain. Melalui bahasa seseorang dapat mengungkapkan pikiran dan perasaannya baik secara lisan maupun tulisan. Begitu pentingnya bahasa dalam kehidupan sehari-hari tidak dapat dielakkan lagi karena hampir setiap aktivitas dan kegiatan yang dilakukan melibatkan bahasa, baik bahasa lisan maupun bahasa tulis. Sebagaimana ditegaskan ahli bahwa bahasa adalah sistem lambang bunyi yang arbitrer yang digunakan untuk bekerja sama, berinteraksi dan mengidentifikasikan diri (Chaer, 2007:32 Alber dan Febria, 2018:78; Nalenan, 2019:103-104; ).

Bahasa yang digunakan secara tulisan dapat dilihat dari keterampilan menulis seseorang. Keterampilan menulis merupakan kegiatan yang mempunyai peranan penting di dalam kehidupan manusia, karena dengan menulis seseorang dapat mengungkapkan pikiran, perasaan dan gagasan kepada orang lain secara logis dan berkesinambungan dengan menggunakan bahasa yang sesuai dengan kaidah penggunaan bahasa yang baik dan benar.

Salah satu kegiatan menulis yang penting dilakukan oleh siswa di sekolah adalah keterampilan menulis karangan deskripsi. Menulis karangan deskripsi merupakan salah satu kompetensi dasar (KD) yang terdapat di kelas X. Adapun tujuan dari pembelajarannya adalah agar siswa mampu untuk mencatat topik-topik dapat dikembangkan menjadi karangan deskripsi berdasarkan pengamatan, menyusun kerangka karangan deskripsi, mengembangkan kerangka yang telah disusun menjadi karangan deskripsi, menggunakan frase adjektifa dalam karangan deskripsi, dan menyunting karangan deskripsi yang telah ditulis oleh teman.
Keraf (dalam Mahargyani dkk, 2012) menjelaskan tulisan deskripsi merupakan sebuah bentuk tulisan yang bertahan dengan usaha para penulis untuk memberikan perincian-perincian dan objek yang sedang dibicarakan. Semi (2003:41) menjelaskan bahwa deskripsi bertujuan untuk memberikan perincian atau detail tentang objek sehingga dapat memberikan pengaruh pada sensitivitas dan imajinasi pembaca atau pendengar bagaikan mereka ikut melihat, mendengar, merasakan, atau mengalami langsung objek tersebut. Selanjutnya, menurut Thahar (2008:36) Karangan deskripsi adalah pemaparan atau penggambaran sesuatu berupa benda, tempat, dan suasana atau keadaan. Dalam karangan deskripsi pembaca seolaholah dapat merasakan seperti yang dilukiskan pengarang dalam karangan tersebut

Keterampilan menulis bukanlah hal yang mudah, terutama bagi siswa. Hal ini terbukti dari wawancara yang peneliti lakukan dengan guru bahasa Indonesia bernama Neldawati, M.Pd. Berdasarkan hasil wawancara diperoleh informasi bahwa keterampilan siswa dalam menulis karangan deskripsi masih rendah dan berada di bawah KKM.

Hal yang sama juga terlihat dari hasil observasi pada contoh tulisan siswa dalam menulis tugas karangan diketahui bahwa siswa kelas X SMA Negeri 1 Bangkinang memiliki keterampilan menulis yang rendah. Hal ini terbukti dari beberapa kesalahan yang terdapat dalam tulisan siswa, seperti rincian tentang objek, pengaruh sensitivitas dan membentuk imajinasi kepada pembaca, gaya yang memikat dan pilihan kata yang tepat, memaparkan tentang sesuatu yang dapat didengar, dilihat, dirasakan, dan susunan ruang. Rendahnya keterampilan siswa dalam menulis karangan deksripsi juga terbukti dari hasil penelitian yang dilakukan oleh Heriasa (2014)

Pengaruh Model Pembelajaran Kooperatif Tipe Cooperative Integrated Reading And Compositi (CIRC) dan Minat Baca Terhadap Keterampilan Menulis Karangan Deskripsi Siswa Kelas X SMA Negeri 1 Bangkinang 
menyatakan sebagian besar siswa terlihat kurang aktif dalam mengikuti pembelajaran menulis karangan deskripsi. Hal ini disebabkan siswa kurang mampu menggunakan bahasa Indonesia dengan baik dan benar terutama pemilihan diksi atau kata yang digunakan pada karangan.

Untuk mempermudah siswa dalam menulis karangan deskripsi ini diperlukan wawasan yang luas agar siswa dengan mudah mengungkapkan ide-idenya dalam bentuk tulisan. Melalui membaca siswa dapat memperluas wawasan dan pengetahuannya. Oleh sebab itu, siswa harus dapat meningkatkan minat baca agar memperluas pengetahuan yang mereka miliki. Menurut Sudiana (2004) minat baca merupakan salah satu faktor yang berpengaruh secara signifikan terhadap kemampuan membaca dan menulis. Selanjutnya, Tarigan (2008:105) menjelaskan minat baca adalah sikap mencurahkan perhatian akan sikap ingin tahu yang intelektual dan bijaksana serta ditambah dengan suatu usaha konstan untuk menggali bidang-bidang pengetahuan atau informasi baru, dan adanya kesediaan yang menyediakan waktu untuk melakukan kegiatan tersebut. selanjutnya, Sudiana (2004) menjelaskan bahwa usaha peningkatan minat baca dapat ditempuh dengan cara, yaitu (1) memilihkan materi bacaan yang menarik; (2) memilih cara pembelajaran yang menarik; (3) memberikan kemudahan memperoleh berbagai macam bahan bacaan yang menarik dan yang sesuai dengan kebutuhannya; (4) memberi kesempatan membaca bebas; (5) menanamkan kesadaran pentingnya membaca dalam kehidupan, terutama untuk mencapai keberhasilan di sekolah.

Selain minat baca, faktor lain yang diasumsikan mempengaruhi hasil menulis karangan deskripsi siswa kelas X SMA Negeri 1 Bangkinang, yaitu metode pembelajaran yang digunakan guru bahasa Indonesia masih menggunakan metode ceramah. Hal ini juga disampaikan oleh ibu Neldawati, M.Pd dalam wawancara, beliau menyampaikan bahwa masih banyak guru menggunakan metode cermah dalam menyampaikan materi kepada siswa. Syah (2007:122) menjelaskan bahwa dalam proses pembelajaran, salah satu faktor penentu hasil belajar yang akan dicapai siswa adalah faktor pendekatan pembelajaran. Faktor pembelajaran itu meliputi jenis, strategi, dan metode pembelajaran yang digunakan dalam pembelajaran.

Model pembelajaran CIRC dipandang efektif digunakan dalam pembelajaran pembelajaran menulis karangan deskripsi karena model pembelajaran CIRC merupakan suatu model yang mengajak siswa untuk menyelasaikan masalah secara bersama-sama dan memahami bacaan dengan saling membacakan contoh teks. Selain itu, tujuan utama dari $C I R C$ adalah menggunakan tim-tim kooperatif untuk membantu siswa dalam mempelajari kemampuan memahami bacaan yang dapat diaplikasikan secara luas, sedangkan untuk pelajaran menulis dan seni berbahasa adalah untuk merancang, mengimplementasikan, dan mengevaluasi pendekatan proses menulis pada pelajaran menulis dan seni berbahasa yang akan banyak memanfaatkan kehadiran teman satu kelas, Slavin (dalam Novika, dkk, 2014).

Berdasarkan uraian di atas, dapat disimpulkan bahwa minat baca dan model pembelajaran kooperatif tipe CIRC diasumsikan dapat berpengaruh terhadap hasil keterampilan menulis karangan deskripsi. Jadi, pengaruh minat baca dan model pembelajaran kooperatif tipe CIRC terhadap menulis karanngan deskripsi, yaitu minat baca yang tinggi dan terarah akan membantu siswa untuk mengungkapkan ide-idenya ke dalam tulisan dan mampu menulis karangan deskripsi dengan baik. Sementara itu, penggunaan model pembelajaran kooperatif tipe CIRC akan membantu mereka untuk aktif dalam belajar dan memecahkan masalah pembelajaran dengan cara belajar dan berdiskusi dengan kelompok kecil. Apabila siswa diajarkan dengan model pembelajaran CIRC dan siswa memiliki minat baca yang tinggi, maka diduga mereka akan lebih mampu untuk menulis karangan deskripsi dengan baik.

Pengaruh Model Pembelajaran Kooperatif Tipe Cooperative Integrated Reading And Compositi (CIRC) dan Minat Baca Terhadap Keterampilan Menulis Karangan Deskripsi Siswa Kelas X SMA Negeri 1 Bangkinang 
Fenomena yang berkembang berkaitan dengan rendahnya hasil keterampilan menulis karangan deskripsi, penggunaan model pembelajaran CIRC, dan minat baca yang dimiliki oleh siswa, mendorong peneliti untuk mengetahui gambaran secara lebih pasti dan mendalam mengenai pengaruh model pembelajaran CIRC dan minat baca terhadap keterampilan menulis karangan deskripsi. Oleh sebab itu, penelitian ini penting dilakukan untuk menjelaskan apakah terdapat pengaruh model pembelajaran kooperatif tipe $C I R C$ dan minat baca terhadap keterampilan menulis karangan deskripsi siswa kelas X SMA Negeri 1 Bangkinang.

Berdasarkan rumusan masalah di atas, maka tujuan penelitian ini adalah (1) Menjelaskan perbedaan hasil menulis karangan deskripsi siswa dengan menggunakan model pembelajaran $C I R C$ dan model pembelajaran konvensional. (2) menjelaskan perbedaan hasil menulis karangan deskripsi siswa dengan minat baca tinggi yang diajar dengan menggunakan model pembelajaran CIRC dengan yang diajar dengan model pembelajaran konvensional, (3) menjelaskan perbedaan hasil menulis karangan deskripsi siswa dengan minat baca rendah yang diajar dengan menggunakan model pembelajaran CIRC dengan yang diajar dengan model pembelajaran konvensional, dan (4) menjelaskan interaksi antara model pembelajaran $C I R C$ dengan minat baca dalam mempengaruhi keterampilan menulis karangan deskripsi siswa kelas X SMA Negeri 1 Bangkinang.

\section{METODOLOGI PENELITIAN}

Penelitian ini merupakan penelitian kuantitatif dengan menggunakan metode eksperimen semu (quasy exsperiment). Metode eksperimen semu yaitu penelitian yang bertujuan untuk memperoleh informasi dari eksperimen berdasarkan perlakuan (treatmen) terhadap suatu unit percobaan dalam batasbatas desain yang ditetapkan pada kelas eksperimen sehingga diperoleh data untuk menggambarkan apa yang diharapkan. Desain penelitian yang digunakan adalah factorial design (2x2) (Wahyuni et al., 2015; Wahyuni \& Etfita, 2018).

Populasi penelitian adalah seluruh siswa kelas X SMA Negeri 1 Bangkinang, tahun ajaran 2015/2016 berjumlah 151 siswa. Penarikan sampel dengan menggunakan teknik purposive sampling. Sampel penelitian diambil dengan cara mengumpulkan nilai ulangan harian siswa, melakukan uji normalitas, uji homogenitas, menentukan kelas eksperimen dan kelas kontrol. Berdasarkan hasil uji normalitas dan uji homogenitas, maka kelas yang dipilih menjadi sampel penelitian adalah kelas X1 sebagai kelas kontrol dan kelas X5 sebagai kelas eksperimen.

Penelitian ini terdiri atas tiga variabel. Pertama, variabel independen (variabel bebas) adalah variabel yang menyebabkan perubahan terhadap variabel dependen. Variabel independen dalam penelitian ini adalah model pembelajaran kooperatif tipe CIRC. Kedua, variabel dependen (variabel terikat) adalah variabel yang dipengaruhi oleh variabel independen. Pada penelitian ini variabel dependen adalah keterampilan menulis karangan deskripsi. Ketiga, variabel moderator adalah variabel yang memperkuat hubungan antara variabel independen dan dependen. Pada penelitian ini yang berperan sebagai variabel moderator adalah minat baca.

Instrumen penelitian terdiri atas dua, yaitu angket, dan tes unjuk kerja. Angket digunakan untuk mengetahui minat baca siswa dan tes unjuk kerja digunakan untuk mengetahui hasil keterampilan menulis karangan deskripsi.

Angket minat baca yang digunakan untuk uji coba terdiri atas 50 item pernyataan. Setelah dilakukan uji validitas dengan menggunakan rumus korelasi Product Moment, diperoleh 38 butir pernyataan valid dan reliabel, kemudian 12 pernyataan tidak valid dan reliabel. Jadi, 38 butir pernyataan dapat digunakan sebagai instrumen penelitian.

Selanjutnya, langkah-langkah pengumpulan data, yaitu sebagai berikut. Pertama, angket diberikan kepada siswa.

Pengaruh Model Pembelajaran Kooperatif Tipe Cooperative Integrated Reading And Compositi (CIRC) dan Minat Baca Terhadap Keterampilan Menulis Karangan Deskripsi Siswa Kelas X SMA Negeri 1 Bangkinang 
Kedua, siswa mengisi setiap pernyataan dalam lembaran angket dengan membubuhkan tanda centang. Ketiga, siswa diberikan tes unjuk kerja untuk mengukur keterampilan menulis karangan deskripsi. Keempat, siswa diberikan waktu 90 menit untuk membuat sebuah karangan deskripsi berdasarkan tema yang mereka pilih pada lembaran unjuk kerja yang sudah diberikan siswa mengerjakan tes unjuk kerja menulis. Kelima, semua lembar jawaban yang telah terkumpul diperiksa sesuai dengan aspek dan kriteria yang telah ditetapkan.

Selanjutnya, dilakukan pengujian persyaratan analisis, yaitu (1) uji normalitas dengan menggunakan rumus Lilliefors dan (2) uji homogenitas dengan menggunakan uji $\mathrm{F}$. Kemudian dilanjutkan dengan pengujian hipotesis 1,2,3 menggunakan rumus uji-t dan hipotesis 4 menggunakan rumus analisis varians (anava) uji $\mathrm{F}$.

\section{HASIL DAN PEMBAHASAN}

Pada bagian ini penulis menganalisis kemampuan siswa kelas X SMA Negeri 1 Bangkinang dalam menulis karangan deskripsi. Analisis difokuskan pada kemampuan siswa dalam menulis karangan deskrpsi dengan menggunkan metode pembelajaran kooperatif tipe CIRC dan konvensional. Selain model pembelajaran yang digunakan, penulis juga menganalisis mint baca yang dimiliki oleh siswa. Analisis data ini dilakukan atas hasil dari tulisan karangan deskripsi siswa belajar dengan menggunakan model pembelajaran koperatif tipe $C I R C$ dan konvensional. Adapun hasil dari analisis datanya sebagai berikut.

1. Keterampilan Menulis Karangan Deskripsi Siswa yang Diajar dengan Model CIRC dan Metode Konvensional

Hasil pengujian hipotesis pertama menunjukkan bahwa hasil secara keseluruhan keterampilan menulis karangan deskripsi siswa yang menggunakan model pembelajaran Kooperatif tipe CIRC lebih baik daripada keterampilan menulis siswa yang menggunakan model pembelajaran konvensional. Hal ini juga ditunjukkan dari nilai yang diperoleh siswa pada kelas eksperimen lebih tinggi dibandingkan dengan nilai yang diperoleh siswa pada kelas kontrol. Temuan penelitian ini sejalan dengan pendapat Sulistyaningsih, dkk (2002) model pembelajaran kooperatif tipe $C I R C$ merupakan model pembelajaran yang mengajak peserta didik bekerjasama dan berpartisipasi aktif dalam diskusi kelompok agar siswa lebih bersemangat dalam belajar dan berinteraksi antar peserta didik, sehingga dapat meningkatkan keaktifan peserta didik dalam belajar. Oleh sebab itu, Penerapan model pembelajaran kooperatif tipe $C I R C$ merupakan salah satu model pembelajaran yang dapat membantu siswa memahami bagaimana cara mempelajari suatu konsep materi secara efektif dan efisien.

Berbeda dengan model pembelajaran kooperatif tipe $C I R C$, model pembelajaran konvensional menggunakan komunikasi satu arah yang menempatkan siswa sebagai objek belajar yang berperan sebagai penerima informasi secara pasif. Pada umumnya, penyampaian pelajaran menggunakan tanya jawab dan penugasan. Guru selalu mendominasi kegiatan pembelajaran, sedangkan siswa lebih banyak menerima dari guru. Hal ini sesuai dengan pendapat Djafar (2001:3) yang menyatakan bahwa model pembelajaran konvensional merupakan model yang berorientasi pada guru dan hampir seluruh kegiatan belajar mengajar dikendalikan penuh oleh guru.

Berdasarkan uraian di atas dapat disimpulkan bahwa untuk mencapai tujuan pembelajaran dengan baik diperlukan suatu model pembelajaran, termasuk dalam pembelajaran keterampilan menulis. Agar tujuan pembelajaran keterampilan menulis tercapai dan terealisasi dengan baik dibutuhkan model pembelajaran yang dapat melibatkan siswa untuk memecahkan suatu masalah dalam pembelajaran dengan cara belajar dan berdiskusi dengan kelompok kecil. Salah satu model yang dapat digunakan dalam pembelajaran menulis adalah model pembelajaran kooperatif tipe $C I R C$.

Pengaruh Model Pembelajaran Kooperatif Tipe Cooperative Integrated Reading And Compositi $($ CIRC) dan Minat Baca Terhadap Keterampilan Menulis Karangan Deskripsi Siswa Kelas X SMA Negeri 1 Bangkinang 
2. Keterampilan Menulis Karangan deskripsi Siswa yang Memiliki Minat baca Tinggi yang Diajar dengan Model Pembelajaran CIRC dan Model Pembelajaran Konvensional

Hasil penelitian di SMA Negeri 1 Bangkinang pada pengujian hipotesis kedua menunjukan bahwa keterampilan menulis karangan deskripsi siswa yang memiliki minat baca tinggi yang diajar menggunakan model pembelajaran kooperatif tipe CIRC lebih tinggi daripada siswa yang memiliki minat baca tinggi yang diajar menggunakan model pembelajaran konvensional. Nilai yang dipeoleh siswa pada kelas eksperimen lebih tinggi dibandingkan dengan nilai yang diperoleh siswa pada kelas kontrol.

Perbedaan keterampilan menulis karangan deskripsi pada kelas eksperimen dan kelas kontrol, dengan tingkat minat baca yang tinggi dapat dilihat dari nilai rata-rata tes keterampilan menulis karangan deskripsi yang berbeda. Secara keseluruhan siswa yang memiliki minat baca tinggi di kelas eksperimen memperoleh nilai keterampilan menulis karangan deskripsi di atas KKM. Hal ini disebabkan oleh pengaruh dari perlakuan yang diterapkan pada kelas eksperimen tersebut. Akan tetapi, berbeda dengan kelas kontrol yang hanya menggunakan model pembelajaran konvensional. Rata-rata keterampilan siswa di kelas kontrol dalam menulis karangan deskripsi yang di atas KKM.

Temuan penelitian ini juga didukung oleh pendapat Slavin (2009:200) menyatakan bahwa model pembelajaran kooperatif Tipe CIRC merupakan sebuah program komperhensif dalam pengajaran membaca, menulis, dan seni berbahasa pada kelas yang lebih tinggi di sekolah dasar. Pada model ini siswa bekerjasama dalam tim, dan pembelajaran beranggotakan sekitar empat orang. Mereka terlibat dalam sebuah rangkaian bersama termasuk saling membacakan satu dengan yang lainnya, membuat prediksi bagaimana cerita naratif yang akan muncul, menulis tanggapan terhadap buku yang dibacakan, saling membuat resensi. Artinya, guru memberikan peluang kepada siswa untuk mengembangkan aktivitasnya dengan berbagai cara peranan guru hanya sebagai pembimbing, pendorong, pemberi fasilitas sehingga siswa berkembang sendiri dan berdiskusi dengan teman kelompoknya siswa yang memiliki minat baca tinggi secara otomatis akan mempunyai pengetahuan yang tinggi sehingga akan mudah dalam mengikuti setiap langkah dalam model pembelajaran kooperatif tipe CIRC ini secara tidak lansung, siswa yang memiliki minat baca tinggi tersebut akan mudah memecahkan permasalahan yang ada dalam materi yang disajikan.

Berdasarkan penjabaran di atas, dapat disimpulkan bahwa untuk mencapai tujuan pembelajaran yang diinginkan diperlukan minat baca, termasuk dalam pembelajaran keterampilan menulis. Keterampilan menulis setiap siswa akan berbeda, sesuai dengan tingginya minat baca yang ada pada masingmasing siswa. Siswa yang memiliki minat baca yang tinggi terhadap pembelajaran menulis karangan deskripsi akan memperoleh hasil yang lebih baik dibandingkan dengan siswa yang memiliki minat baca yang rendah. .

3. Keterampilan Menulis Karangan Deskripsi Siswa yang Memiliki Minat Baca Rendah yang Diajar dengan Model CIRC dan Model Konvensional

Hasil pengujian hipotesis ketiga menunjukan bahwa keterampilan menulis karangan deskripsi siswa yang memiliki minat baca rendah yang diajar dengan model pembelajaran CIRC lebih tinggi daripada siswa yang memiliki minat baca rendah yang diajar menggunakan model pembelajaran konvensional. Nilai yang diperoleh siswa pada kelas ekpserimen lebih tinggi dibandingkan dengan nilai yang diperoleh siswa pada kelas kontrol.

Dalam pembelajaran menunujukkan keterampilan menulis karangan deskripsi siswa yang memiliki minat baca rendah yang diajar menggunakan model pembelajaran CIRC lebih tinggi daripada siswa yang memiliki minat baca rendah yang diajar menggunakan model konvensional. Akan tetapi, walaupun sama-

Pengaruh Model Pembelajaran Kooperatif Tipe Cooperative Integrated Reading And Compositi (CIRC) dan Minat Baca Terhadap Keterampilan Menulis Karangan Deskripsi Siswa Kelas X SMA Negeri 1 Bangkinang 
sama memiliki minat baca rendah, nilai tes keterampilan menulis karangan deskripsi di kelas eksperimen tetap tinggi daripada kelas kontrol. Hal ini disebabkan oleh pengaruh perlakuan model pembelajaran CIRC yang diterapkan pada kelas eksperimen tersebut.

Sejalan dengan yang dijelaskan sebelumnya, walaupun siswa yang minat baca rendah di kelas eksperimen ini lebih tinggi nilai keterampilan menulis karangan deskripsi daripada kelas kontrol, peningkatan minat baca pada kelas tersebut perlu dilakukan. Menurut Sugiono (2015:18) bahwa membaca buku harus berproses. Anak-anak tingkat SMP dan SMA/SMK harus dibiasakan membaca buku yang bersifat informatif yang menumbuhkan kreatifitas bereksperimen. Dengan kata lain, minat baca akan tumbuh jika informasi yang disajikan buku memacu pembaca untuk lebih tahu. Dengan demikian, siswa akan memperoleh informasi tersebut dan mudah menuangkannya dalam karangan deskripsi.

Berdasarkan uraian di atas dapat disimpulkan dapat disimpulkan bahwa model pembelajaran yang menarik dan mudah dipahami siswa, maka dapat meningkatkan kreativitas siswa dalam proses pembelajaran. Hal ini tentu akan memberikan dampak positif bagi proses pembelajaran terutama dalam pembelajaran menulis karangan deskripsi. selain itu, minat baca siswa juga harus ditingkatkan agar siswa dapat menambah pembendaharaan kata bagi siswa. Hal ini tentunya akan membuat siswa merasa menulis karangan deskripsi tidaklah sulit.

4. Interaksi antara Model Pembelajaran CIRC dan Minat Baca dalam Mempengaruhi Keterampilan Menulis Karangan Deskripsi

Suatu interaksi dapat terjadi apabila efek faktor yang satu tergantung pada faktor lainnya dalam mempengaruhi sesuatu (Irianto 2004: 225). Ini berarti masing-masing faktor antara model $C I R C$ dengan minat baca saling tergantung satu sama lainnya dalam mempengaruhi keterampilan karangan deskripsi. Proses interaksi antar variabelvariabel tersebut dapat dijelaskan sebagai berikut.
Berdasarkan uji Anava terhadap hipotesis keempat dapat diketahui bahwa tidak terdapat interaksi antara model pembelajaran CIRC dengan minat baca dalam mempengaruhi keterampilan menulis karangan deskripsi. Hal ini berarti menunujukkan bahwa siswa yang memiliki minat baca tinggi maupun minat baca rendah, apabila diajar dengan menggunakan model pembelajaran CIRC tidak memberikan pengaruh trehadap hasil keterampilan menulis karangan deskripsi.

Temuan penelitian yang menyatakan bahwa tidak terdapat interaksi antara model pembelajaran CIRC dengan minat baca juga dapat dilihat dari rata-rata hasil tes keterampilan menulis karangan deskripsi. Hal tersebut terjadi pada kedua tingkat minat baca, baik tinggi maupun rendah, yang sama-sama diajar dengan menggunakan model pembelajaran CIRC. Rata-rata nilai keterampilan menulis karangan deskripsi siswa minat baca tinggi dan rendah di kelas eksperimen lebih tinggi daripada siswa minat baca tinggi dan rendah di kelas kontrol. Seperti yang terlihat dalam grafik interaksi berikut.

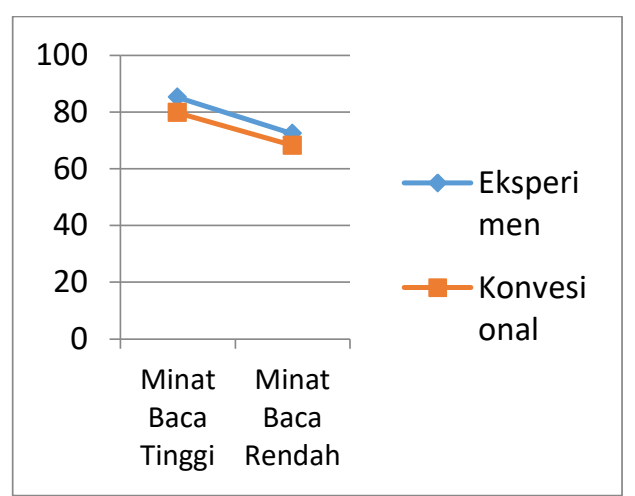

Gambar 11. Gafik Interaksi antara Model CIRC dengan Minat Baca terhadap Keterampilan Menulis Karangan Deskripsi

Pada gambar 11 terlihat perbedaan rata-rata di kelas eksperimen dan kelas kontrol, yaitu pada siswa yang memiliki minat baca tinggi yang diajarkan dengan model pembelajaran CIRC memiliki rata-rata 85,17 , sedangkan siswa yang memiliki minat baca tinggi yang diajarkan dengan model

Pengaruh Model Pembelajaran Kooperatif Tipe Cooperative Integrated Reading And Compositi (CIRC) dan Minat Baca Terhadap Keterampilan Menulis Karangan Deskripsi Siswa Kelas X SMA Negeri 1 Bangkinang 
konvensional memiliki rata-rata sebesar 79,67.

Siswa yang memiliki minat baca rendah yang diajarkan dengan model pembelajaran CIRC memiliki rata-rata 72,33 , sedangkan siswa yang memiliki minat baca rendah yang diajarkan dengan model konvensional memiliki rata-rata sebesar 68,17. Berdasarkan dari sisi kolom tidak adanya interaksi memberi arti bahwa pada model pembelajaran CIRC, antara siswa yang memiliki minat baca tinggi dan siswa yang memiliki minat baca rendah tidak ada perbedaan dalam kemampuan menulis karangan deskripsi dan hal yang sama berlaku jika dilihat pada metode konvensional.

Dengan tidak terdapatnya interaksi tersebut, dapat disimpulkan bahwa masingmasing faktor dari model pembelajaran CIRC dan minat baca tidak saling bergantung satu sama lainnya dalam mempengaruhi hasil keterampilan menulis karangan deskripsi pada kelas eksperimen dan kelas kontrol. Walaupun demikian, model pembelajaran CIRC terlihat lebih efektif diterapkan pada kedua tingkatan minat baca tersebut. Dengan kata lain, model pembelajaran CIRC tepat diterapkan untuk siswa yang memiliki minat baca tinggi dan dapat juga diterapkan pada siswa yang memiliki minat baca rendah.

Temuan penelitian ini juga didukung oleh penelitian relevan yang dilakukan oleh Novika, dkk (2014) yang menyatakan tidak ada interaksi antara penggunaan model pembelajaran CIRC dan kemampuan membaca terhadap keterampilan menulis narasi, berdasarkan analisis data inferensial dengan teknik ANOVA dua jalan di atas diperoleh Fo $=0,41$. Dari tabel distribusi $\mathrm{F}$ dengan $\mathrm{dk}$ (derajat kebebasan) pembilang $1 \mathrm{dan} \mathrm{dk}$ penyebut $=106$ pada taraf nyata $=0,05$ diperoleh $\mathrm{Ft}=3,94$ yang lebih besar dari Fo. Dengan demikian, dapat disimpulkan bahwa tidak ada pengaruh gabungan atau interaksi antara penerapan model pembelajaran dan kemampuan membaca terhadap keterampilan menulis narasi siswa.

\section{SIMPULAN}

Berdasarkan deskripsi, analisis dan pembahasan terhadap data yang dilakukan, hasil penelitian ini dapat disimpulkan sebagai berikut

1. Keterampilan menulis karangan deskripsi yang diajarkan dengan menggunakan model pembelajaran CIRC lebih baik daripada siswa yang diajar menggunakan model pembelajaran konvensional siswa kelas X SMA Negeri 1 Bangkinang

2. Keterampilan menulis karangan deskripsi siswa yang memiliki minat baca tinggi yang diajar dengan model pembelajaran CIRC lebih baik daripada keterampilan menulis karangan deskripsi siswa yang memiliki minat baca tinggi dengan model pembelajaran konvensional.

3. Keterampilan menulis karangan deskripsi siswa yang memiliki minat baca rendah yang diajar dengan menggunakan model pembelajaran CIRC lebih baik daripada keterampilan menulis karangan deskripsi siswa yang memiliki minat baca rendah yang diajar dengan model pembelajaran konvensional.

4. Tidak adanya interaksi antara model pembelajaran CIRC dengan minat baca dalam mempengaruhi keterampilan menulis karangan deskripsi.

\section{REFERENSI}

Alber, A., \& Febria, R. (2018). Analisis Kesalahan Berbahasa Tataran Sintaksis dalam Kumpulan Makalah Mahasiswa Universitas Islam Riau. In GERAM (Vol. 6, Issue 2). https://doi.org/https://doi.org/10.25299/g eram.2018.vol6(2).2143

Chaer, A. (2007). Linguistik Umum. Rineka Cipta.

Nalenan, J. S. (2019). Bentuk Bahasa Kasual Guyub Tutur di Wilayah Perumahan BTN Kefamenanu. JUBINDO, 4(1).

Novika.,Dkk, 2014. "Pengaruh Model Pembelajaran Cooperative Integrated Reading and Composition (CIRC) dan Kemampuan

\footnotetext{
Pengaruh Model Pembelajaran Kooperatif Tipe Cooperative Integrated Reading And Compositi (CIRC) dan Minat Baca Terhadap Keterampilan Menulis Karangan Deskripsi Siswa Kelas X SMA Negeri 1 Bangkinang
} 
MembacaTerhadapKeterampilan Menulis Narasi Siswa Kelas VII SMP Negeri di Kabupaten Ngawi". Jurnal Penelitian Bahasa, Sastra Indonesia dan Pengajarannya. Vol. 1, No. 3. Wahyuni, S., \& Etfita, F. (2018). Pengaruh Blended Learning Model dan Sikap Berbahasa terhadap Kemampuan Menulis Bahasa Inggris Siswa Sekolah Menegah Atas Negeri di Kota Pekanbaru. Geram (Gerakan Aktif Menulis), 6(1), 1-9.

Wahyuni, S., Putri, M. E., \& Ilyas, M. (2015). The effects of teaching media and language attitude towards students' listening skill at state junior high schools in Depok. English Education International Conference, 126-134.

Pengaruh Model Pembelajaran Kooperatif Tipe Cooperative Integrated Reading And Compositi (CIRC) dan Minat Baca Terhadap Keterampilan Menulis Karangan Deskripsi Siswa Kelas X SMA Negeri 1 Bangkinang 